\title{
THE SMOLENSK REGION ONYM \\ IN THE BACKGROUND KNOWLEDGE OF MOSCOW STUDENTSHIP (BASED ON THE ASSOCIATIVE EXPERIMENT)
}

\author{
N.V. Bubnova \\ Military Academy of Army Air Defence of the Armed Forces of the Russian Federation \\ (Smolensk, Russian Federation) \\ E-mail: 85ninochka67@mail.ru
}

\begin{abstract}
Studying associative and cultural background of proper nouns became especially topical in early $21^{\text {st }}$ century, in conditions of sweepingly developing globalization, resulting in gradual leveling of national and cultural uniqueness of a language-speaking nation. The other side of the globalist process is an enhanced feeling of ethnic, national and cultural distinctiveness, as any proper noun is adapted to such reflection by its own nature of a unique denomination of a single object. Any name accumulates in its content a large volume of historical and cultural information, and, thus, it is one of the basic units in the background knowledge of the cultural heritage, maintaining a link betwixt generations within an ethnocultural community. Nationwide cultural space (in particular, national onomasticon) is formed by an aggregate of regional subsystems; in this connection, studying and description of a regional material facilitate further structuring and description of the national material. The Smolensk land holds a special place in the nationwide cultural space. Its millennium-long history is represented by the names of outstanding people and reflected in the names of numerous architectural and cultural memorials, being the national heritage of Russia. In this regard, studying associative and cultural background of the Smolensk region toponym will considerably enrich linguistic and culturological explorations. We used a large-scale associative experiment as a basic method to detect associative and cultural background of the capital regional onym of Smolensk. This article presents results of one of the experiment's stages attended by 826 students of various universities of Moscow. Generally, according to the experiment results, reactions of the respondents quite fully and exactly reflect linguistic-cultural realia related to the Smolensk region toponym. The obtained results indicate that the considerable part of Smolensk regional background knowledge (in particular, onomastic ones) is associated with the nationwide level, thus forming a significant part of national cultural space. The described approach to detect and analyze associative and cultural background of capital regional onyms can be used by researches in other regions of Russia.
\end{abstract}

Keywords: associative and cultural background; associative experiment; proper noun (onym); background knowledge; linguistic personality.

\section{Introduction}

Creators of the culture-oriented linguistics word theory (E.M. Vereshchagin, V.G. Kostomarov, Yu.E. Prokhorov, G.D. Tomakhin, etc.) actively 
developed the question of the cultural semantics involved in the content of the proper noun in the second half of the $20^{\text {th }}$ century. Therefore, G.D. Tomakhin emphasized, "Onomastic lexis possesses the lofty national and cultural markedness. Any toponym and anthroponym in linguistic and cultural spheres are perceived against the background of the determined associations based on certain features of the object denominated by them. More than that, the background knowledge being held by speakers of the certain language and culture materially differ not only in volume, but also in the form of their existence. Thuswise, during the culture-oriented linguistic exploring of lexis it's necessary to take into account not only all meanings of a word fixed in dictionaries, but also its associations in the background knowledge of native speakers" [1:115].

In the modern linguistics, exploring the proper noun as a 'cultural sign' is one of the most perspective directions of onomastic research. As E.Yu. Voyakina noted, "The proper nouns contain information about the country's history, religious preferences, culture and the mentality of the people. Onyms carry out the cumulative function of accumulation, preservation and transmission of knowledge from one generation to another, being supports in communication. The capability of the proper nouns to acquire optional meanings, connotations, to accumulate associative, figurative and emotional elements under the influence of linguistic and extra linguistic factors stipulate their heightened claim that indurates in the distinction of information contained in the initiate semantics of the proper nouns" [2: 35]. The particular significance and claim of exploration of multiplane national and cultural information in the contents of onym was aggrandized in the beginning of the $21^{\text {st }}$ century against the background of fast-moving globalization (especially, mental globalization that its processes develop more intensively), which is mentioned in the investigation summary.

The regional direction is a highly essential topic in the present-day native onomastic investigations. It is reflected in proceedings of noted linguists such as A.K. Matveev, E.L. Berezovich, M.V. Golomidova, M.E. Rut, N.A. Maximchuk and other scientists. Investigations in the regional onomastics are not only protuberant to describe unique onomastic space of certain regions and their historical and cultural peculiar features, but also to objectively describe nationwide onomastic rolls.

\section{Methodology}

We have been exploring the associative and cultural background of the Smolensk region toponym for 10 years. According to the associative and cultural background, following N.A. Maximchuk, we comprehend this as "all attendant information that is not the part of the immediate content of the onym. At the same time, the "cultural component indicating the background 
knowledge accompanying the proper noun primarily bears the culturologically peculiar feature (in this case culture is realized in a large sense). Associative component indicates the main path to forming, extending and discovering new background knowledge" [3: 166], that is the associative experiment.

A large-scale association experiment is the main method of our study. N.V. Ufimtseva identifies four benefits of the research material revealed by this experiment: 1) the correlation of associative reactions semantic structure of the vocabulary of language structure; 2) due to the associative reaction proper determining language syntagmatic bonds words; 3 ) the ability to judge by the associative reactions about the "rules" of the joint use of words in speech; 4) obtaining results of association studies specific to the culture and language of "associative profile" images of consciousness, integrating a mental and sensory knowledge, which a certain ethnic group has [4: 181].

When using the method of associative experiment to describe the associative and cultural background onomastic units it is important that the selection in the vast area of the stereotypical association experiment provides basis-typicality of talk about a certain set of associations for native speakers and their individual groups. The phenomenon of typical reactions (not only in the formal language, but also in the aspect of content) allows us to define, share structure and content of the associative and cultural background of any language units.

The experiment has been conducted by us at the regional (Smolensk) and national level. The main results obtained in the course of the experiment at the regional level characterizing the features of the associative and cultural background toponym the Smolensk region in the perception of the respondents, are described in detail in our dissertation research [5] and the monograph [6].

In this phase of the work, we are exploring the content of the Smolensk region toponym and "the Smolensk component" of the background knowledge generally on the nationwide level. In the beginning of the research, we elucidated how the Smolensk region is described in the lexicographical and culture-oriented linguistic sources and in the Russian National Corpus [7]. Afterwards, we offered the Smolensk region toponym as a motivation for Moscow and Saint Petersburg respondents to compare in what degree the composition of the background knowledge of Smolensk formulated by various sources coincides with the feasible composition of the background knowledge of the nationwide language person. Nowadays, 1602 respondents have participated in the experiment: 826 students of Moscow and 776 students of Saint Petersburg higher education institutions.

\section{Research results and analysis}

In this work we place the emphasis on the description of results of the experiment that was conducted with the Moscow students. The number of ex- 
periment students of each higher education institution in the descending order was as follows: Moscow State University of design and technologies (234); Moscow state technical university named after N.E. Bauman (174); Moscow Regional State University (172); Russian State University for the Humanities (137); Military University of the Defense Ministry of the Russian Federation (62); The Russian Presidential Academy of National Economy and Public Administration (29); Pushkin State Russian Language Institute (18).

At the beginning of the experiment, respondents were offered to fill in anonymous questionnaires highlighting the following characteristics: gender, age, academic curriculum vitae, birthplace (Moscow/Saint Petersburg or other city/township), education (secondary education/post-secondary education/higher education), future professional sphere (humanitarian/technical), native language(s). After the questionnaires were filled in, probationers were offered to write reactions for the Smolensk region motivation during one minute.

Acquired associative material was processed via creation of Electronic Data Base in Microsoft Office Access involving 1140 types of reactions (3101 use). Among the most common reactions (frequency index is $\geq 10$ ) is 42 (relevant frequency index is for each reaction; here and further the graphic layout of the respondents' answers is absolutely observed): Smolensk (136); city (107); resin (84); village (82); war, hero-city (67 for each one); Russia (56); province (48); history (47); district (43); forests (41); the Great Patriotic War (34); fields (31); roads (30); the Ancient Russia (25); Kremlin (24); war of 1812, village (22 for each one); the Dnieper river (21); village, nature (20 for each one); people (19); the Smolensk battle (18); the Smolensk region (17); Do You Remember The Roads Of Smolensk region, Alexey? (16); battle, boundary, fortress, the Smolensk road (15 for each one); far, the Ancient Russia, churches (13 for each one); Napoleon, cathedral (12 for each one); hick, river, church (11 for each one); city of Russia, mud, earth, the Smolensk war, verse (10 for each one).

As the result of the analysis of the most common reactions associated by students of Moscow academies with the Smolensk region motivation, we have conducted following observations:

1. The most common reaction is the Smolensk onym. To our mind, this is not only the characteristic of administrative and geographical relations that are identified in the perception of the respondents, but also close connection of the center and the whole region. In this unity of the center and periphery the unicity of small province areas contrasted with the dissociation of the capital and its huge areas is shown here (Moscovites are used to sneer at this: Is there life behind the Moscow Beltway?). The close co-relation of Smolensk and the whole area of Smolensk region in conceptions of the respondents explain to us that a part of reactions for the determined motivations intersects another one. Thus, reactions for city, hero-city, and city of Russia definitions are reactions for the Smolensk motivation, and region, the 
Smolensk region, earth - for the Smolensk region motivation. The reaction for hero-city should be especially underlined in which the second component of the lexical token holds the great meaning. By the $40^{\text {th }}$ anniversary of the victory in the Great Patriotic War on May, 61985 the Supreme Soviet of the USSR issued the order: "Hero-city honorary title and the Gold Star medal must be awarded to Smolensk for the courage, firmness, mass heroism, and efforts that were displayed by the Smolensk people in the fight against the Nazi invaders during the Great Patriotic War" [8: 426].

2. A group of the most common reactions such as village, province, small town and also forest, field, river, nature characterize the Smolensk region as a province and reflects its opposition to the metropolis according to the determined features in the realization of Moscow students. Regarding this, reaction for $f a r$ is extremely revealing here, it might be called arguable, because the distance from Smolensk to Moscow is $393 \mathrm{~km}$. At the same time, for instance, the distance from the metropolis to the farther area of Greater Moscow Area called "Serebryanie Prudy" is $160 \mathrm{~km}$. Reactions characterizing nature matters place the emphasis on "the province feature" of the Smolensk region and reflect the stereotyped and associative connection of the province (village) and nature.

We can separately emphasize the most common reaction, which is hick, whose origination for the Smolensk region motivation is explained by the formal sound similarity. However, in the view of linguistics these accordant words have an absolutely different interpretation. In this case, during the research we initially were guided by the opinion of Z.A. Potikha, according to which the present suffix -schin-(щuн) in the composition of the Smolensk region toponym characterizes "the formation of the proper nouns with the place meaning". The features of nouns formed by means of the same suffix do not extend to them. These proper nouns generally mean everyday occurrence, ideological passages with the trace of the negative attitude to them (barshchina (corvee) and so on)" [9:231]. To note parenthetically, in a classification of all acquired reactions in the view of their informative value (the classification is illustrated below) the group of formal reactions based on the sound similarity with the motivation has been outlined by us as a separate substantive group; Potikha's comment spreads to the whole group of such reactions.

3 . The resin reaction characterizes the etymology of the Smolensk lands' names that is shown in the inward form of the Smolensk toponym that was noticed by the probationers. In the meantime, there are several versions of the city name origination. Replies of the respondents have something in common with Farmer's version. In his largest etymologic dictionary the origination of the Smolnya hydronym and the name of the city are recorded [10: 690].

In the opinion of O.N. Trubachev, the name of the city descended from the verb smoliti with the meaning 'to clear forest with aid of fire', 'to 
burn forest down'. It also descended from the ancient form and the meaning of the verbal root *smol-, *smoliti- [9: 105]. At the same time, not only the attitude to the forest is expressed in the name of Smolensk people. The necessary connection with agriculture is also reflected here because in other words *smolěne are the Slavs who retook the tilled field of the forest [11: 105].

Several research findings (beginning from the noted Smolensk historian of the $19^{\text {th }}$ century, S.P. Pisarev), whose points of view we share, consider that Smolensk as a center of Krivich [12:12] tribes was named according to the denomination of the particular Slavic tribe Smolyane (Smolene), which settled at the Dnieper hilly bank and gave the name to the city [13: 3]. The demonstration of the independence of these ancient Smolensk people consisted in that fact they did not participate in the calling of the Varangians like, for instance, the Krivich tribes did, to whose composition they belonged [Ibid.: 6]. The toponymists shared the viewpoint of S.P. Pisarev: V.A. Nikonov who gave the linguistic comment of the city name origination - from the name of the inhabitants (that is the tribe): smolyane + -sk suffix [14: 387], and B.A. Makhotin who came to a conclusion that Smolensk is the "city of the Smolensk people" [15: 10].

To note parenthetically, the probationers called the people reaction and it is the most common one. Moreover, at the same time, the respondents singly called only one Smolensk demonym - Smolensk female. The respondents did not call other names of the Smolensk inhabitants such as the Smolensk people, smolyane. In our opinion, in this case we cannot affirm that the probationers meant the Smolensk female. Therefore, in particular, in the analysis of materials of the Russian National Corpus for the purpose of the presence of the Smolensk component in it, we revealed that the Smolensk females were fosterdaughters of the Smolniy School of Noble Maidens in Saint Petersburg [16]. What is more, it was also a kind of small arms. Perhaps, one of the motivated bases explains to us the origination of such a reaction.

4. The Russia and the Ancient Russia reactions are evidence of that the Smolensk land is primarily the Russian land in consciousness of the respondents despite the fact that Smolensk land belonged to different states and princedoms in different periods. Since 882 it belonged to the Kievan Rus (the Smolensk princedom was established just in 1054); since 1404 up to 1514 it belonged to the Great Lithuanian princedom, since 1611 up to 1654 it belonged to the Polish Lithuanian Commonwealth. The fact that the present-day young people associate the Smolensk region with the Russian component can be differently interpreted: as ignorance of the Smolensk region's history by the capital cities students and the simple verification of its administrative and territorial belonging or as the purposeful act of ascribing of the Smolensk land to Russia. In this case, it is complicated to make a monosemantic conclusion but it is worth noting that reactions related to the Smo- 
lensk region historical past were nevertheless mentioned by the respondents, for example: Poland, the Polish-Lithuanian Commonwealth.

In the content of the Ancient Rus reaction, apart from the characteristic of the territorial belonging of the Smolensk region, the same as ancient is not less important (the same is reflected in the most common reaction history). Actually, the Smolensk lands have ancient history: the city was built on the ancient trade route named as "from the Varangians to the Greeks" as a city of Krivich tribes' union. The first mention of Smolensk in the chronicle is referred to 863 . At that time, as a chronicler wrote, there was "the great city with great population" [8: 423].

The boundary reaction reflects the frontier location of the Smolensk lands: Velizhskiy district, Ershichskiy district, Krasninskiy district, Monastyrshchinskiy district, Rudnyanskiy district, Khislavichskiy district and Shumyachskiy district border on Vitebsk region and Mogilyov region of the Belorussian Republic.

5. A particular group of the most common reactions is formed by reactions that characterize the Smolensk region military history such as war, the Great Patriotic War, the war of 1812, the Smolensk battle, a battle, Napoleon, the Smolensk war. The popularity of reactions of such a thematic connection is well grounded, since the Smolensk history can actually be named as the war history. The fate of Smolensk is reflected in its national titles: the guard city, the shield city, the key city. The respondents' reactions reflect all main guideposts of the Smolensk military history: Russian-Polish wars: the Smolensk war statement naming just the Russian-Polish war of 1632-1634 requires an extra comment here; the Patriotic War of 1812: on the $16^{\text {th }}-17^{\text {th }}$ of August the noted Smolensk battle happened that was the defensive battle of the consolidated Russian army (Armies of M.B. Barclay de Tolly and P.I. Bagration) against Napoleon's army. It prevented an easy march of French forces to Moscow; the Great Patriotic War of 1941-1945: Smolensk battles continued for 2 months (from July 10 to September 10 of 1941). They resulted in the end of the Nazi offensive on Moscow.

Interestingly, in the content of the nationwide knowledge especially shown in the Russian National Corpus, the quantity of contexts related to the Smolensk military history prevails over the quantity of all the rest of the contexts, which underlines the particular role of the Smolensk earth in the military history of Russia [7, 17, 18].

6. The group of the most common reactions with the general lexical element a road also arouses our interest: a road (roads), the Smolensk road, "Do you remember the Smolensk region roads, Alexey..." (In addition, a rejoining reaction to this group called as a verse that obviously calls K. Simonov's text). The Smolensk region roads have significant historical connections. The old Smolensk road was the shortest overland way to Europe for years. Occurrence of such a reaction can be related to the popularity of 
B. Okujava's song named as "On the Smolensk road" which was written in 1960. The Smolensk region proper noun is consistently connected with the decisional text in the content of the background knowledge of Russian linguistic personality "Do you remember the Smolensk region roads, Alexey..." which was written by K. Simonov in 1941. As N.L. Leiderman noted, "the Smolensk region roads" is the trustworthy positive and at the same time significant figure. Once upon a time, Napoleon followed these roads. Afterwards, Hitler tanks left for Moscow on these roads. At the beginning of the Great Patriotic War, 25-years-old Simonov joined the army and became the "Red Star" correspondent. As a military correspondent, he was sent to the west boundary where the main attack of Hitler armies was conducted and saw the tragic beginning of the war". Actually, being then impressed by the most tragic war months he wrote this text [19: 63].

7. Reactions such as the Dnieper; a church (churches), a cathedral; the Kremlin, a fortress name the fundamental waterway, the highest relic and the main architectural fortification of the Smolensk region conformably. According to the results of the experiment with the respondents, indeed these three proper nouns were the most common (in brackets, the frequency index is determined for each name): the Dnieper (953), the Cathedral Church of the Assumption (725), the Smolensk rampart (695) [6]. Sites named by these onyms are actually a "calling card" of Smolensk.

8. The last most common reaction expressing the negative assessment of the respondents is $m u d$; unfortunately, it reflects the objective condition of the city. However, there is a question where did they get this information from (this question would not arise, if this reaction was not the most common; and we could simply assert that several research participants either were born in Smolensk, or visited these places). In this case, we can conjecture there can be a stereotype of associative link: the Smolensk region is a province. To note parenthetically, during the classification of all acquired material in the result of the experiment, the group of estimating reactions was distinguished as substantive group (the information can be shown below). The quantity of negative reactions in this group exceeds the quantity of positive reactions. The conducted co-relation is 86 to 35 conformably.

Totally, the acquired material (from the described most common reactions to the singular ones) was classified by different fundamentals. At the same time, particularly, in the point of view of cognatic status (cognatic potential), we distinguish generally valid, individual reactions and reactions with the unclear motivational backbone. There is a number of individual reactions such as res $\mathbf{5}$, a friend $\mathbf{4}$, a camp $\mathbf{3}$, relatives $\mathbf{3}$, a former boyfriend $\mathbf{1}$, perfect weekend 1 etc. It composes a small percentage of the total quantity of reactions (76 reactions from 1140 ones; $6.6 \%$ ) and is an exponent of availability of generally valid informative knowledge about the Smolensk region. Individual reactions are out of the scope of our investigation. There is a 
small group of reactions (69 from 1140;6\%) whose motivational backbone of origin is obvious only for the respondents who called such reactions, for instance: Barbie doll, bears going by bicycle, sakura, fugra, spider man, etc. They are also out of the scope of our investigation. All these reactions are presented singularly and characterize the ignorance of informative components of the associative and cultural background of the Smolensk region toponym by their authors.

Among of the valid reactions in the substantial attitude we point the following types out: 1) informative, 2) evaluative, 3) formal, 4) mistaken and 5) "hollow". We are going to consider the following reactions:

1) INFORMATIVE REACTIONS (825/2671): The absolute majority of reactions (825 from 1140, 72\%) are informative ones, c'est-a-dire they reflect the critical components of the associative and cultural background of the explored onym.

In pointing out the semantic groups of informative associations, we noticed that the composite reactions encompass two and more semes (for instance, the Ancient Rus, the historical city, the Russian city, the historical ancient city of Russia), and we determined their thematic belonging based on the semantic belonging of the first component of the word-group.

Upon the quantitative analysis of the informative reactions, we disclosed the following peculiar features of the obtained associative material:

1) the respondents called reactions-word forms we considered as one reaction indicating the second form, for instance: a village 85 (villages 3 inclusive);

2) single-rooted words and phenomena of the syntactical derivation are considered as one reaction, for instance: mushroom $\mathbf{1}$ (mushis 1), gloomil $\mathbf{2}$ (gloomy 1);

3) the proper nouns that call one culture-specific concept but are expressed by various lexical means were considered as different reactions (imagine them as micro groups for demonstrativeness), as a supplementary component of the composite onym enriches its content and testifies to the availability of relevant knowledge of the probationers, for instance: the Assumption Cathedral in Smolensk, the Assumption Cathedral, etc.

Informative reactions can be presented as 25 semantic groups (in order to observe all requirements (genre, volume), we shall consider the first ten groups). In brackets is presented the quantity of forming reactions/quantity of performances as assigned to each semantic group; groups are in the descending order from the total amount to the amount of repeated reactions: (143/593):

I. Reactions describing the Smolensk region as a province

1. Reactions characterizing the Smolensk region as a province 22/214: a village 85 (villages 3 inclusive); a province 48; a big village 22; a habitation 21 (habitations 1 inclusive); backs 9; outskirts 5; circumference 4; 
thicket 3; village life, agriculture, silence 2; a depth, by-place, countryside, quietude, provincialism, a provincial town, a rural settlement or hick people (c'est-a-dire, the word describes this phenomena), tranquil peaceful life, tranquilly, easy life schedule, quietly 1.

2. Reactions describing the nature of Smolenshchina 29/155:

2.1. Nature 20; vastitude $\mathbf{8}$ (vastitudes $\mathbf{3}$, roomily $\mathbf{1}$ inclusive); fresh midair 3; picturesque nature 2; midair, splendid natural places, beauty of nature, the sky, sceneries, expanse, freshness, fresh midair, ecology $\mathbf{1 .}$

2.2. Forest 41 (forests 19 inclusive); a tree 14 (trees 5 inclusive); a birch $\mathbf{5}$ (birches 2, littlebirches $\mathbf{1}$ inclusive); a fir $\mathbf{3}$ (firs $\mathbf{1}$ inclusive); an oak, green grass, brushes, firs, vegetation, cones $\mathbf{1}$.

2.3. The Dnieper 21; a river $\mathbf{1 3}$ (rivers 1; brooks $\mathbf{1}$ inclusive); a bog 5 (bogs $\mathbf{3}$ inclusive); a lake $\mathbf{3}$ (lakes $\mathbf{1}$ inclusive); the Dvina, the Osma $\mathbf{1}$.

3. Reactions reflecting the connection with Russian traditional culture 41/108: batter cakes, the Shrovetide, atradition 10 (traditions 1 inclusive); a peasant's log hut, a samovar $\mathbf{8}$; handicraft, a trade fair $\mathbf{5}$ (trade fairs $\mathbf{2}$ inclusive); abagel 4 (bagels 3 inclusive), a tissue 4 (tissues 1 inclusive); felt boots, a loaf, a cart, national 3; a stove, a spice-cake, a shirt, traceries, folklore 2; a balalaika, a baranka, the Gzhel, an open-air merrymaking, a headband, the Pillsbury dough-boy, a national blacksmith's shop, straw shoes, national art, a nation, national songs, a custom, the national clothing, a national song, dancing, alkie, fairytales, souvenirs (a plate, a piece of magnet, a bell), round dances and other Russian cultural elements, painted wood article, ditties, a cap with earflaps $\mathbf{1}$.

4. Reactions characterizing peculiar features of the Smolensk region landscape and agriculture of its inhabitants 35/87:

4.1. A field 31 (fields $\mathbf{1 3}$ inclusive); hills 4; grasslands 2; highlands, woodlands, wooden well-fare, a wood line, woods and grasslands, thin forest, a trench, the Smolensk grasslands, a wilderness 1.

4.2. Collective farms 7; a garden $\mathbf{2}$ (gardens $\mathbf{1}$ inclusive); an agrarian complex, milkmaids, stockbreeding, an apiary, tillage, a plough, field labor, agronomy, farms, housekeeping $\mathbf{1}$.

4.2.1. A cow 7 (beef, cows 1 inclusive); animals, a horse (horses), a kitty (cats) 2; domesticated animals, chickens, cattle, a dog $\mathbf{1}$.

4.2.2. Bears $\mathbf{2}$; a wolf $\mathbf{1}$.

5. Reactions describing buildings of the Smolensk region 15/28:

5.1. A house 7 (houses $\mathbf{3}$ inclusive); ramshackle houses $\mathbf{3}$; a way of life (small houses), wooden houses, peasant's log huts, old buildings 2; a village house, small houses, edifices, the Stalin buildings, antique edifices, private houses 1.

5.2. A well 2.

6. Other 1/1: absence of the underground $\mathbf{1}$. 


\section{Reactions characterizing the interconnection of the Smolensk region and Smolensk as an administrative center (40/376):}

1. Reactions with the Smolensk lexical token 5/140: Smolensk 136; the Smolensk city and its outskirts, Smolensk and its outskirts with adjoining habitations/villages, Smolensk and the Smolensk region, beside Smolensk 1.

2. Reactions with the city lexical token 35/236: a city 107; the propaganda of the city, something related to the city 1.

2.1. The hero-city $\mathbf{6 7}$; a hero 5 ; a brave city 1.

2.2. The Russian city 10; the city in Russia $\mathbf{2}$.

2.3. A non-great city 7 ; a small city $\mathbf{6}$; a small town; a picturesque small city; not a very big city $\mathbf{1}$.

2.4. Evaluation of the city by respondents:

2.4.1. A beautiful city, a beautiful Russian city, a fabulous city, a city in progress 1 .

2.4.2. An unfavorable city, a boring and small city 1.

2.5. The geographic location of the city:

2.5.1. There is a city hereabouts, a city that is located not so far $\mathbf{1}$.

2.5.2. The city located nearby Belorussia; a state boundary city; a boundary city; a through city $\mathbf{1}$.

2.6. The strategic city, it was often an arguable city $\mathbf{2}$.

2.7. The city located on seven hills 2.

2.8. The city was named so, because in the ancient time boats were caulked and put afloat there $\mathbf{1}$.

2.9. A native city $\mathbf{2}$; a childhood city; the city I am going to travel to $\mathbf{1}$.

2.10. The city is unknown!; the noted city $\mathbf{1}$.

2.11. The State emblem of the city 1.

III. Reactions describing the Smolensk military history (96/305):

1. Reactions reflecting the wealth of the military history of the Smolensk land (without pointing out the concrete wars and combat operations) (51/187): a war 70 (wars 3 inclusive); the Smolensk battle 18; a battle 15; a defensive 5; a revolt, an uprising 4; a military event 3 (military developments 1 inclusive), the Smolensk battle 3; a fight 2 (fights 1 inclusive); a blockade, combat actions, a besiege, a battle 2; the conquest of Smolensk, the Smolensk military operation, a subjugation, a name of battle, invasion, furious fighting, militia, guard, battles, participation in wars 1.

1.1. Guerillas, soldiers 3; veterans 2; troops, heroes $\mathbf{1}$.

1.2. Blood $\mathbf{3}$, a gun $\mathbf{3}$ (guns $\mathbf{2}$ inclusive); a tank $\mathbf{3}$ (tanks $\mathbf{2}$ inclusive); a battlefield 2; trenches, powder, shooting 1.

1.3. Heroism 2; combat glory, military glory, a deed $\mathbf{1}$.

1.4. An army, the front $\mathbf{2}$; the Smolensk regiment $\mathbf{1 .}$

1.5. Artillery (weaponry), weaponry experts, weaponry beauty, weaponry 1.

1.6. Memory, victory, a scouting force $\mathbf{1}$. 
2. The Smolensk region wars 43/116:

2.1. The Great Patriotic War 1941-45 12/46: the Great Patriotic War 34; 1941 2; $13^{\text {th }}$ division of the national militia (my grand grandfather militated there), the Smolensk battle in the Great Patriotic War, the Great Patriotic War battles, the Smolensk battles in the Great Patriotic War, the city played the most urgent role in the Great Patriotic War, the defense of Smolensk in the Great Patriotic War, the Smolensk battle of 1941, the Solovyev ferry 1.

2.1.1. World War II, the Second World War 1.

2.2. The Patriotic War of 1812 15/54: the war of 1812 22; Napoleon 12; fire 3; 1812, the Smolensk battle of 1812 2; the war of 1812 (the Smolensk battle), the war against Napoleon, a gathering area of Russian troops in the war of 1812, Napoleon fell back beside Smolensk, the siege of Smolensk by Napoleon, the Smolensk battle of 1812, the Smolensk battle in the war of 1812, Frenchmen 1.

2.2.1. Borodino 3 .

2.3. The Russo-Polish war of 1632-34 3/12: the Smolensk war 10; the battle against the Poles, the war against Poland $\mathbf{1}$.

2.4. The Russia-Lithuanian war of 1512-22 1/2: 15142.

2.5. World War I of 1914-18 1/1: the First World War 1.

2.6. The Great Northern War 1700-21 1/1: Lewenhaupt's column 1.

3. The Smolensk land evaluation in the history of the Russian State 1/1: All campaigns in Russia will be terminated nearby Smolensk $\mathbf{1}$.

4. Other 1/1: missing somewhere in the Smolensk region 1.

IV. Reactions naming sights of the Smolensk region (61/98):

1. Churches and monasteries 30/93: a church 24 (churches 13 inclusive); a cathedral 17 (cathedrals 5 inclusive); a temple 10 (temples 8 inclusive); a monastery 3; cupolas 2; a great number of churches, wooden temples, a lot of temples, a lot of churches, non-great churches, the Smolensk cathedrals, the Ancient Rus churches, churches and temples, small churches $\mathbf{1}$.

1.1. The Assumption Cathedral of the Holy Mother: the Cathedral Mountain 3; the Holy Assumption Cathedral, the Assumption Cathedral, the Smolensk Cathedral 2; the Cathedral church, the Assumption Cathedral 1.

1.1.1. The Smolensk icon of Odigitriy 7; orthodoxy, the saints 1.

1.2. Other churches and monasteries: the Abramius monastery, the Voznesenskiy monastery, the Smolensk Abramius monastery, the Smolensk church, the Trinity monastery, Michael Archangel's church 1.

2. Monuments, museums and homesteads 31/105: a monument 10 (monuments $\mathbf{7}$ inclusive); a museum 4 (museums $\mathbf{1}$ inclusive); sights $\mathbf{3}$; homesteads $\mathbf{2}$; historical monuments $\mathbf{1}$.

2.1. The Smolensk defensive wall: the Kremlin 24; a fortress 15; the defensive wall, the Smolensk Kremlin 7; the Kremlin of Smolensk, the Smolensk defensive wall 3; the defensive gates (wall), the Smolensk fortress, the 
Russian land necklace, the Smolensk fortress, the Old Kremlin, a wall, the watch tower of the Smolensk Kremlin $\mathbf{1}$.

2.2. Monuments: the Immortality tumulus 4; the Heroes' Parkway of 1812, the eternal light 2; "the Lions' house", the Deer in the park, the Great Patriotic War monument on the road, the Lenin monument, the Tvardovskiy and Tyorkin monument, monuments (to Z. Kosmodemyanskaya) $\mathbf{1}$.

2.3. Museums and homesteads: the Gagarin Museum 2; beautiful castles, the Great Patriotic War museum, Glinka's homestead $\mathbf{1}$. (76/192):

V. Reactions-characteristics of Smolensk and the Smolensk region

1. The Smolensk region as a historical land 60/167:

1.1. Reactions with the history same 20/72:

1.1.1. History 47; Russia's history 3; rich history, the Ancient Russia's history, historical period, a period in Russia's history, a period of history 1.

1.1.2. A historical object, a historical center, a historical site 2 ; a historical event 2 (historical events inclusive); historical value; historical (especially, military) events happened in the region, a historical city; Russia's historical ancient city, historical period, historical term (the rich history), historical time $\mathbf{1}$.

1.1.3. It is historically bound up with Moscow 1.

1.2. Reactions with semes such us antiquity/eld/langsyne (olden time) 17/53:

1.2.1. The Ancient Russia 13; antiquity 7; the ancient city 4; ancient 5; the Old Russian city 2.

1.2.2. The old city 5; Russian old city 3; old (eld) 2; one of the oldest cities of Russia, the Old Russia, the old big village; the old splendid city 1.

1.2.3. Langsyne (old times) 4; Russian old city 2; a part of langsyne, the antique city, the antique city with a lot of parks $\mathbf{1}$.

1.3. Reactions describing objects/events of olden time 18/36:

1.3.1. Georgics 7; boyars, a prince, a czar 4; a rank of a boyar (boyar's wife), a war boss, Cossacks, the Krivich tribes, merchants (merchantry), Rurikids, the Slavs 1.

1.3.2. Epic heroes 2; an epic hero, the boyar troops, the prince's armored force $\mathbf{1}$.

1.3.3. A town's meeting, type of government (feudal), feudalism $\mathbf{1}$.

1.4. Reactions with the lexical token such as a century 5/6: the Middle Ages 2 ; a century, $19^{\text {th }}$ century, $20^{\text {th }}$ century, the beginning of $20^{\text {th }}$ century 1.

2. Color associations 9/15: green 4 (greenery 2 inclusive); yellow, black 2; blackness $\mathbf{2}$ (black $\mathbf{1}$ inclusive); white, green, red, gray, blueness $\mathbf{1}$.

3. Reactions characterizing the perception of the motivation by the size 2/5: small 4; big 3 .

4. Culture-bound items and developments related to the modern history of Smolensk 3/3: the game "By fire and sword"; a mother of many chil- 
dren that is suspected of the high treason; the Nationalist Liberal Democrats political social movement $\mathbf{1}$.

5. Other features 2/2: new, familiar to Vladimir $\mathbf{1}$.

VI. Reactions reflecting the Smolensk region belonging to the Russian State in different periods (35 / 121):

1. Motherland 7; a state, a small motherland, patriotism, a country 1.

2. The Russian earth belonging in different historical periods:

2.1. From the Ancient Russia to the Modern Russia 1.

2.2. The Ancient Russia 25; the cradle of the Ancient Russia, the roots of the Ancient Russia, the period of the Ancient Russia's consolidation, Mother Russia 1.

2.3. The empire, Czarist Russia $\mathbf{1}$.

2.4. The Soviet Union, the USSR 1.

2.5. Russia 56; something is situated in the Russian Federation, the Russian Federation, the RF, a part of Russia, this is in Russia $\mathbf{1}$.

3. Reactions with the lexical token such as Russian: Russian 2; the Russian province, the Russian woman, the Russian land, Russian, Russian women at the cart, Russian women, the Russian traditions, the Russian, the Russian morale, the Russian nation, the Russian language, the Russian architecture $\mathbf{1}$.

VII. Reactions with the Smolensk region roads seme (33/119):

1. A road $\mathbf{3 0}$ (roads $\mathbf{1 2}$ inclusive).

1.1. "Do you remember the roads of the Smolensk region, Alexey?" 16; a verse 10; Alexey 6; the roads of the Smolensk region, a verse 1.

1.2. The Smolensk road 15; the Smolensk passage 2; retreat of the enemy on the Smolensk road, the Smolensk road (1812), the Old Smolensk road 1.

1.2.1. "On the Smolensk road" 1.

2. The characteristics of the Smolensk roads:

2.1. Horrible roads $\mathbf{6}$; impassibility of roads $\mathbf{2}$; no roads, absence of asphalted roads, absence of roads, a road washed out by rain $\mathbf{1}$.

2.2. The road to Belorussia, we are moving to Belorussia, the key road to Moscow 1.

2.3. An earthenware road (an argillic road), a country road, ramifications of roads $\mathbf{1}$.

3. The Minsk highway $3 ; 242^{\text {nd }}$ kilometer of the Minsk highway is the pedestal of the Bauman warriors $\mathbf{1}$.

4. A train 5; trains, a commuter train 2; a railway, a locomotive, a platform, the "Swallow" train, a trip $\mathbf{1}$.

\section{Reaction characterizing the Smolensk region geographic lo- cation (57/118):}

1. The place on Russia's map 6/11: $67^{\text {th }}$ region, a map 3; geography 2; the region in the central part of Russia (European part) with rich history, Central Russia, the central district 1. 
2. The location relative to Moscow 23/48:

2.1. Far 13; far from Moscow 6; expanse 4 (far, farther $\mathbf{1}$ inclusive); $a$ far region $\mathbf{2}$ (far regions $\mathbf{1}$ inclusive).

2.2. Nearby 2; nearby Moscow, not far, not far from Moscow, relatively close to the Moscow outskirts, beside Moscow 1.

2.3. Behind the Moscow Beltway 2; areas behind the Moscow Beltway, not the Moscow Beltway, $400 \mathrm{~km}$ from the Moscow Beltway 1.

2.4. 8-hour route, $400 \mathrm{~km}, 400 \mathrm{~km}$ to the west from Moscow, 6-hour trip to Moscow by train 1.

2.5. "The Moscow Gates" 2; the Gates of Moscow, the New Moscow, it is not Moscow 1.

3. The frontier location 15/40: a frontier 16 (frontiers 1 inclusive); the West $\mathbf{8}$; the West of Russia $\mathbf{3}$; motion to the West $\mathbf{2}$; close to the frontier, the gates of Russia, the gates, the west direction, the west military district, the first line, the frontier station, the frontier territory, a line, the strategic frontier location $\mathbf{1}$.

4. The frontier territories $\mathbf{1 3 / 1 9 :}$

4.1. Belarus, the frontier with Belorussia 3; on the border with Belorussia, nearby Belorussia 2; Belorussia, Belarusians, the nearness to Belorussia, the Minsk direction, on the way to Belorussia, not far from the boundary with Belorussia, in the neighborhood of Belarus $\mathbf{1}$.

4.2. Bryansk, nearby Bryansk $\mathbf{1}$.

IX. Reactions-dominations of the territorial elements of the Smolensk region (15/98): a region 43; the Smolensk region 17; land 10; the princedom $\mathbf{6}$; the government $\mathbf{5}$; the Smolensk princedom, a region $\mathbf{3}$; a district, a territory $\mathbf{2}$; the princedom of Smolensk, a locality, a site, a district, a borough 1.

\section{$X$. Reactions characterizing the etymology of the Smolensk topo- nym (11/94):}

1. Resin 84; resin food; it is apparently generated from the word such as resin; a tool with resin work; a resin maker $\mathbf{1}$.

2. Travelers, a path, the path "From the Varangians to the Greeks", the Smolensk boats, merchants, a trade route 1.

Therefore, according to the semantic relation reactions for the motivation of the Smolensk region compose different groupings, whose composition names and describes quite fully and accurately the historical objects and cultural-bound items related to the Smolensk region. Moreover, the most prevalent repeated reactions (used upward of 300 times) are the semantic groupings that possess: 1) the description of the Smolensk region as a province; 2) the interrelation of Smolensk and the Smolensk region as an administrative center; 3) the description of the Smolensk region military history that is regular and correlates with the composition of the more common reactions mentioned before. 
2) ESTIMATIVE REACTIONS (8/120; 7\%):

2.1. The negative evaluation and connotation 56/86: mud 10; brutality 6; coldness (cold $\mathbf{2}$ inclusive); poorness, idleness $\mathbf{3}$, etc.

2.2. The positive evaluation 23/35: goodness 4; beauty, glory, warmness $\mathbf{3}$; interest, tranquility, coziness $\mathbf{2}$, etc.

The composition of this reaction grouping shows us that reactions with negative evaluation prevail in the quantitative relation (in some cases, they are accompanied with the reduced stylistic nuance, for instance: trash, sheeple, a hole, etc.). What is more, in some cases, there is a question about the addressee of the negative reactions (such as ignorance, illiteracy, gaucherie, absence of imagination, etc.): Using this way, the respondents characterize the Smolensk region inhabitants or themselves.

3) FORMAL REACTIONS (41/73; 3.5\%):

3.1. Associations conditioned by the presence of suffixes such as -shchin, -ishch, -in or the sound [sh'] in words with the silent word stem 19/47: hick 11, apathy 8, woman 6; Pugachev's Rebellion 3; hazing in the military, Zadonshchina, Seven Boyars, Khovanshchina 2; corvee, boyarhood, bream, filbert, man, a nickname $\mathbf{1}$.

3.2. Associations based on the assonance with the first element of the proper noun 12/16:

3.2.1. Smol 3; Smolnyi 2; the Smolnyi bund, the Smolnik, the Smolnyi Institute, resin (moth) 1.

3.2.2. Fyodor Smolov 2.

3.2.3. A hookah, nicotine, cigarette, tobacco, smoke 1.

Associations based on the presence of the sound [sh'] compose a subgrouping of the formal reactions in different word-formative formants or in the stem of the lexical token. Moreover, we must place the emphasis on that the part of such reactions is based on the non-complicated sound similarity with motivation (such as hick, a woman, hazing of the military, etc.). The other part of reactions is based on the sound similarity with motivation and at the same time encompasses multidimensional historic and cultural information. So, for instance: the apathy is a term introduced by N.A. Dobrolyubov in the noted article named as "What is the apathy?" themed on Goncharov's novel "Oblomov"; Pugachev's Rebellion is non-scientific name that was given by historians to the Peasant's War of 1773-75 under the command of Yemelyan Pugachev; "Zadonshchina" is the monument of the Old Russian literature at the end of $14^{\text {th }}$ century $-15^{\text {th }}$ century about the victory of Russian troops headed by the great prince of Moskow, Dimitri Ivanovich (Donskoi) and his cousin Vladimir Andreevich over the Mongol-Tartar Yoke under the command of the Golden Horde of Mamay, etc.

Associations with the word-formative segment smol'-/smol- and reflecting relation to pitching make the second subgrouping of the formal reactions. There is the reaction Fyodor Smolov that denominates a football play- 
er, the forward of the "Krasnodar" football club and National Russian Team, an idol of the modern youth.

4) MISTAKEN REACTIONS (34/47; 2.9\%) (the necessary corrections and comments are presented in the right order of reaction mention in the article):

4.1. The geographic location of the Smolensk region 9/15:

4.1.1. The Golden Ring of Russia 6: Smolensk is not the part of the Golden Ring of Russia, but this reaction reflects the high assessment of the Smolensk region history in Russia's culture.

4.1.2. $500 \mathrm{~km} \mathrm{2;} 100 \mathrm{~km}$ from Moscow; the region that borders on Moscow region on the northwest; the Moscow outskirts, to the north from Moscow 1: as mentioned in the above article, the distance betwixt Smolensk and Moscow by the highway is $393 \mathrm{~km}$.

4.1.3. South, southwest 1: the Smolensk region is located on the west of European part of Russia.

4.1.4. Regional number is 66 1: International car code of the Smolensk region is 67.

4.2. The proper nouns $\mathbf{7 / 1 0}$ (these onyms are not related to the Smolensk region; only the name of K. Minin is indirectly related to the Smolensk region by the Russo-Polish War of 1609-11, and the name of D. Pozharskiy is not absolutely related to the Smolensk earth):

4.2.1. The Kiev highway 2; Moscow-Brest road 1.

4.2.2. The Volga River 2.

4.2.3. Minin and Pozharskiy 1.

4.2.4. St Paul's Cathedral 1.

4.2.5. The Smolensk citizens 2.

4.3. The honorary title of Smolensk 2/4: the city of military glory 3; the region of the military glory city 1 .

4.4. Specifications of the city $\mathbf{3 / 3}$ : the white city, the wooden city, the Nazi city 1.

4.5. The description of the Smolensk defensive wall 3/3: the whitestone Kremlin, the white Kremlin, the Kremlin of white color 1: the Smolensk defensive wall was made of the red brick; to our opinions, beginnings of such reactions is explained by the fact there is a historical locality in Moscow named as the White City whose construction, like in the case with the Smolensk Kremlin, was headed by Fyodor Kon.

4.6. The description of other non-Smolensk culture-bound items 6/8: mountains $\mathbf{3}$; a big plane in downtown, medical universities, retention of unstressed "o", tuffets, heath 1.

4.7. The Smolensk region history 2/2: the Stone Age, the Copper Riot $\mathbf{1}$.

4.8. Reactions homologating the respondents' low education level $\mathbf{2} / \mathbf{2}$ : wooden stoves (perhaps, the respondents meant wood-fired ovens); a site located nearby the Smolensk outskirts $\mathbf{1}$. 
5) "EMPTY" REACTIONS (15/18; 1.3\%): no associations 3; unfamiliarity 2; everything is complicated, I have no idea, an unknown place, strange, unexplored, unknown region for me, uncertainty, incomprehension of goings-on, misunderstanding, no, Okay Google; I have no idea what this word means; what is this? 1.

We have involved reactions reflecting the respondents' absence of background knowledge related to the Smolensk region motivation in "empty" reactions. The quantity of absolutely empty blanks (the form is filled in only) is 24 units, that is $2.9 \%$ of the total number of blanks. Such results show us that the significant part of the Smolensk region background knowledge belongs to the nationwide level composing the part of nationwide cultural space.

\section{Conclusions}

1. In view of informative value, the experiment reactions can be related to one of the following types: 1) informative reactions describing the associative cultural background of the Smolensk region motivation and language personalities of the respondents; 2) reactions characterizing only collective vocal portrait of the probationers.

2. We have involved individual reactions and reactions with amorphous motivative backbone and estimative, formal, mistaken and "empty" reactions in the grouping of reactions characterizing the collective vocal portrait of the research participants. The individual reactions can be named as discursive reactions, as they reproduce the total fragment of the respondents' worldview about the Smolensk region, in whose composition backbone there are emotionally personal significant events and impressions. Reactions with amorphous motivated backbone are determined by the associative links that are topical for the exact linguistic personality and incomprehensible to others. The mistaken and "empty" reactions are indices of the respondents' ignorance of the associative and cultural background of the Smolensk region proper noun. Anyhow, estimative and formal reactions reflect the respondents' attitude to the set motivation.

3. According to the informative reactions, those reactions that refer to the Smolensk village of the Irkutsk district do not touch the Smolensk region 9/18: there is an opinion that the name expresses the idea that the occupation of this village was pitching (in the past). The Smoliag lived there, people who were occupied with boiling up resin, and the name of the locality was Smoliaga, then - Smolenshchina. Nevertheless, the historical sources contain information about Mitka Smolenskiy who was exiled to the Irkutsk pit in 1670s. The Smolenskikh winter hut is pictured on S. Remezov's map. Perhaps, he was Smoliag and established the Smolensk region [20].

More than that, Smolensk objects of Moscow do not territorially belong to the Smolensk region 13/40 (Smolensk square, Smolensk railway sta- 
tion, Smolenskaya underground station, etc.) and to Russia as well ("Smolensk" undersea cruiser). Naming of Smolensk objects of Moscow by the respondents explains to us that the participants of this experiment were the Moscow students. Each denomination has its own origination that is microscopically described by us [21]. Generally, the exposure and description of Smolensk objects of other Russian cities facilitates in expanding the geography of Smolensk names and determining the role of the Smolensk region and Russia's history.

4. The informative reactions to describe the associative and cultural background of the Smolensk region toponym name denominations, objects, culture-bound items and specifications that are related to the Smolensk region anyhow and afford us to reveal the volumetric historical and culturological information that enriches the associative and cultural background of the investigated toponym. Taking into consideration and observing the volume of the publication and requirements to the genre of this editorial, this multidimensional information is not presented in the real piece of research. In the long view, it can find reflection in different anthropic-oriented dictionaries (such as regional, linguoculturological, associative dictionaries).

5. The methods that are presented in this research can be used to disclose and describe the associative and cultural background of other capital regional proper nouns aimed to objectively describe the nationwide onomasticon.

\section{References}

1. Tomakhin, G.D. (1986). The linguistic aspects of the culture-oriented linguistics. The linguistic issues. 6. pp. 113-118.

2. Voyakina, E.Yu. (2013). The onomastic boom in the modern public policy discourse. Language and Culture. 2 (22). pp. 34-42.

3. Maximchuk, N.A. (2002). The normative and scientific worldview of the Russian linguistic personality in the complex linguistic investigation. Smolensk: the Smolensk University edition. $1.184 \mathrm{p}$.

4. Ufimtseva, N.V. (2004). Associative thesaurus of the Russian language as a model of linguistic consciousness Russian. Language consciousness: theoretical and applied aspects. Moscow; Barnaul: Institute of Linguistics, Russian Academy of Sciences. pp. 177-188.

5. Bubnova, N.V. (2011). The proper nouns in the structure of the Smolensk inhabitants' background knowledge. Smolensk. $285 \mathrm{p}$.

6. Bubnova, N.V. (2013). The regional onomastic background knowledge of the modern Smolensk inhabitants. Smolensk: The Smolensk printing house. 285 p.

7. Bubnova, N.V. (2015). Peculiar features of associative and cultural background of the Smolensk region proper noun in the Russian National Corpus. The Siberian philological magazine. Novosibirsk: The Philological University edition. 3. pp. 223-231.

8. Budaev, D.I. (2003). Smolensk. The Smolensk region: the 2-tome encyclopedia. Under the editorship of D.I. Budaev, G.S. Merkin. Smolensk: the Smolensk University edition. 2. pp. 423-427.

9. Potikha, Z.A. (1970). The Russian modern word-formation. Moscow: Prosveschenie. 384 p. 
10. Fasmer M. (1987). The Russian etymologic dictionary. Translated from German into Russian. Moscow: Progress. 3. 832 p.

11. Trubachev, O.N. (2005). The Smolensk motives. To search for the unity: Grammarian's view to consider the problem of the Ancient Russia's origination. Moscow: Nauka. pp. 93131.

12. Avdusin, D.A. (1957). The Smolensk origination. Smolensk: Edition. 56 p.

13. Pisarev, S.P. (1898). The Smolensk agendum. The historical essay: Indicator and guide. Smolensk: Ya.N. Podzemskiy's printing house. 208 p.

14. Nikonov, V.A. (1966). The concise toponymical dictionary. Moscow: Misl'. 509 p.

15. Makhotin, B.A. (1989). To alive beginnings: The Smolensk region in geographical denominations. Moscow: Moskovskiy rabochiy. $125 \mathrm{p}$.

16. Bubnova, N.V. (2015). The usage of demonym material at the Russian classes aimed to formulate the national consciousness of the Russian linguistic personality. Topical questions to learn Russian (the native language). Ryazan: Esenin's University. 1. pp. 128-132.

17. (2001). The Slavic encyclopedia. The Kiev Russia - Moscovia. Moscow: Olma-Press. 2. pp. 397-398.

18. Bubnova, N.V. (2014). The Smolensk onym in the nationwide background knowledge (based on information of the Russian National Corpus). Language and Culture. 3 (27). pp. 23-41.

19. Leiderman, N.L. (2010). The exploration of the Motherland (K. Simonov "Do you remember the Smolensk region roads, Alexey?"). The philological class. 23. pp. 63-66.

20. Milkheev, M.N. (1969). The geographical denominations of the East Siberia. Available from: http://mirking.com (accessed: 25.10.2014).

21. Bubnova, N.V. (2014). The Smolensk onomastic segment of the Russian National Corpus. The messenger of the Vyatskiy State Humanitarian University. Kirov: Edition. 10. pp. 123-132.

Resived 15.08.2016.

\section{Information about the author}

Bubnova Nina - Ph.D., Associate Professor, Department of Russian Language, Special Faculty, Military Academy of Army Air Defence of the Armed Forces of the Russian Federation (Smolensk, Russian Federation). E-mail: 85ninochka67@mail.ru 